\title{
CYTOTOXICITY ON MCF7 CELL LINES EXPOSED TO AN EXTRACT OF THE JACALIN FROM JACKFRUIT SEED
}

\author{
M. A Zuraidah ${ }^{1 *}$, B. Akbar John² ${ }^{2}$ Y. Kamaruzzaman ${ }^{1}$ \\ ${ }^{1}$ Department of Marine Science, Kuliyyah of Sciences, International Islam University Malaysia, \\ ${ }^{2}$ INOCEM Research Station (IRS), Kuliyyah of Sciences, International Islam University Malaysia, \\ *Corresponding author: idamohdali@yahoo.com akbarjohn50@gmail.com
}

This is an open access article distributed under the Creative Commons Attribution License, which permits unrestricted use, distribution, and reproduction in any medium, provided the original work is properly cited

\section{ARTICLE DETAILS}

\section{Article History:}

Received 3 July 2017

Accepted 3 October 2017

Available online 4 December 2017

\section{Keywords:}

Jacalin, jackfruit seed, cytotoxicity, MCF7, crude extract.

\section{ABSTRACT}

Jacalin is a major lectin present in jackfruit seeds, obtained by crude protein recovery. Its lectin symbol is AIL and it belongs to the galactose family of $\mathrm{N}$-acetylglucosamine binding lectins, which are recognized to be cancer cell inhibitor. There have been many pharmacological research studies focusing intensively on jacalin, however their scope was restricted to the application of jacalin in pharmacology. Jacalin or lectin extract from jackfruit seed were induced cell cycle arrest in human breast cancer cell, MCF7, in comparison of crude extract, purified jacalin and jacalin standard. IC50 for MCF7 was achieved at concentration $125 \mu \mathrm{g} / \mathrm{mL}$, comparable to jacalin standard with only $1.60 \%$ contradictions.

\section{INTRODUCTION}

Worldwide number of deaths due to cancer is increasing despite intensive research into new treatment and preventive. Thus, there is continuous search for new chemotherapeutic drugs by scientific exploitation of the enormous pool of naturally occurring chemicals [1]. The induction of cell death in cancer cells is an ideal strategy for cancer chemotherapy, and the use of agents with this capability has enticed interest in recent years [2]. Plant lectins have a great potential in cancer treatment and have been used to differentiate malignant of cancer cell [3]. Lectins are proteins or glycoproteins of non-immune origin that possess at least one non-catalytic domain that reversibly binds to a specific mono- or oligosaccharide [4-6]. Some plant lectin has been used as alternative therapies in breast cancer patients, such as lemon seed lectin, bauhinia forficate lectin (BfL), mulberry leaflectin, lepidium sativium seed and lectin from G-beauts plant $[3,4,7,8]$.

Lectins are proteins structurally diverse carbohydrate-binding proteins of polysaccharides, glycoproteins or glycolipids from non-immune origin that are able to agglutinate cells or precipitate carbohydrates, without having enzymatic activity towards their carbohydrate. They contain two or more binding sites and can agglutinate cells and/or precipitate complex carbohydrate conjugates. They have been isolated from various plant, animal and bacteria sources, and are widely used in biochemical and cellular studies $[9,10]$. Plants are the richest and most convenient source of lectins, and plant-sourced lectins have been attracting much attention because of their ease of isolation and usefulness as reagents for glycoconjugates in solutions and on the cell surface [11]. Lectins have been revealed to have varying degrees of specificity based on sugar content, conformation and bonding; such as concanavalin A recognizes $\alpha$-Dmannose and $\alpha$-D-glucose, whereas wheat germ agglutinin binds to sialic acid and molecules containing $\mathrm{N}$-acetyl-D-glucosamine residue and jacalin from jackfruit seed binds to a-D-galactosyl groups, which are among the best characterized seed legume ${ }^{3}$. Jacalins are glycoproteins containing approximately 7 to $10 \%$ carbohydrate [12].

In recent years, lectins have become very attractive due to their extensive use as probes for both the characterization and isolation of simple and complex sugars as well as useful tools in immunological studies. Considering the innumerable number of lectins available in nature, the ease with which they can be prepared in purified form. Their flexibility to chemical manipulation and the fact that they can be inhibited by simple sugars makes them attractive as an important tool in biological research. Although lectins are found universally in plant species, they have variable structures and specific activities according to the plants they originate from. Thus, purification and characterization of lectins from a variety of plant species interests many researchers in the field of glycobiology.

Breast cancer cell are the most common malignancy in women, and the two most effective means to reduce mortalities are early detection and better treatment strategies [13]. Nowdays, non-conventional natural treatments have gained wide acceptance due to their promise of a cure with minimal or no side effects, but little scientific evidence exists [8] compared to conventional treatments for breast cancer are costly and have serious side effects. Fruits and vegetables have been shown to contain a diverse source of phytochemicals such as carotenoids, tocopherols and polyphenols which possess chemo-preventive properties at multiples stages of carcinogenesis $[14,15]$. Many dietary agents, such as curcumin (in turmeric) and epigallocatechin gallate (in green tea), have been shown to cause cancer cell inhibitor in many types of cancer cells without affecting normal cells or thereby killing cancer cells specifically without harming normal healthy cells $[8,16]$. One such common remedy is the seed of the jackfruit, which contain lectin as known as jacalin which specific for galactose and has T-antigen specificity, and has widespread potential applications in the medical and pharmaceutical industries. It is a major lectin present in jackfruit seeds, obtained by crude protein recovery, which are recognized to be cancer cell inhibitor [17]. The present research was conducted to investigate the cancer inhibitor potential of this lectin extract. Presented here is the first reported use of the aqueous extract of lectin from jackfruit seed called jacalin on breast cancer cells.

\section{MATERIAL AND METHODS}

All chemicals and biochemical materials used in this study were analytical grade and were purchased with the highest available purity [18]. It was purchased from Fisher Scientific and Sigma. The MCF7 (human breast cancer) cell lines that were used in this study were kindly provided by Dr. Masa-aki Ikeda; Department of Molecular and Carniofacial Embryology, Tokyo Medical and Dental University. The cell lines were maintained in Dulbecco's Modified Eagle Medium (DMEM) medium (with high glucose and glutamine) supplemented with $10 \%$ heat inactivated fetal bovine 
serum (FBS) and $1 \%$ penicillin streptomycin, at $37{ }^{\circ} \mathrm{C}$ in a humidified atmosphere containing $5 \% \mathrm{CO}_{2}$. The MTT assay was used to evaluate the antiproliferative activities of the protein against the cancer cell lines [19]. The assay depends on the cleavage of tetrazolium salt into formazan blue by the mitochondrial enzyme succinate dehydrogenase. The conversion takes place only in living cells and the amount of formazan produced is proportional to the number of viable cells present.

\subsection{Recovery of jackfruit seed extract}

The jackfruit seeds used throughout this study were collected directly from fresh fruits of the jackfruit species Madu Mastura. Jackfruits were obtained from jackfruit farm in Temerloh, Malaysia. Dried seeds, after the removal of shells, were ground to powder form. The following represents a typical extraction procedure, were carried out by PBS precipitation followed by centrifugation and filtration. Ten grams of the powder were mixed with phosphate- buffered saline (PBS, $0.01 \mathrm{M}, \mathrm{pH} 7.4,30 \mathrm{ml}$ ) was soaked as in the pretreatment step at $4^{\circ} \mathrm{C}$ for $24 \mathrm{hr}$. The pretreated sample was then incubated at $4{ }^{\circ} \mathrm{C}$ with constant shaking at $150 \mathrm{rpm}$ for a specified time period in an incubator shaker. All the samples were then centrifuged at 10,000 rpm for $20 \mathrm{~min}$ using Eppendorf Centrifuge $5810 \mathrm{R}$. The clear supernatant was passed through a millipore filter $(0.45 \mu \mathrm{m})$ and the crude protein concentration was measured by the Varian's Cary 50 UV-Vis Spectrometer and calculation of absorbance was done using the Lowry method.

\subsection{Culture cell lines}

MCF7 cells were seeded in complete medium in a 96-well plate at a density of $1 \times 10^{5}$ cells $/ \mathrm{mL}$ and incubated for $24 \mathrm{hr}$ or until cells confluence. In another 96-well plate, a series of sample dilutions were prepared in DMEM ranging within 0 to $200 \mu \mathrm{g} / \mathrm{mL}$. When the cells were confluence, medium was taken out and the cells were washed twice with phosphate buffer solution (PBS) before replacing with new medium of DMEM to ensure complete of nutrition supplied to cell along the treatment conducted. Then, the cells were treated in triplicate in the same 96-well plate with different concentrations of samples and were incubated for $72 \mathrm{hr}$. The medium was then discarded, and the adherent cells were washed twice with phosphate buffer solution (PBS), then $20 \mu \mathrm{L}$ of MTT stock solution (5 $\mathrm{mg} / \mathrm{mL}$ in PBS) were added to each well and the plates were further incubated for $4 \mathrm{hr}$ at $37{ }^{\circ} \mathrm{C}$. Next, $100 \mu \mathrm{L}$ of dimethylsufoxide (DMSO) was added to each well to solubilize the formazan crystals produced by viable cells. After formazan blue was completely dissolved, absorbance was measured at $570 \mathrm{~nm}$ wavelength, using TECAN infinite M200 microplate reader.

\subsection{Cell viability}

Jacalin that had been extracted from crude protein was applied to MCF7 cell lines to study the effectives of jacalin in reducing the viability of cancer cells. This was performed through in vitro study consisting of 96-well plates and examined by 3-(4,5-dimethylthiazol-2-yl)-2,5diphenyltetrazolium bromide (MTT) assay. The MCF7 cell lines that were used in this study were kindly provided by Dr. Masa-aki Ikeda; Department of Molecular and Carniofacial Embryology, Tokyo Medical and Dental University. The cell lines were maintained in Dulbecco's Modified Eagle Medium (DMEM) with high glucose and glutamine supplemented with $10 \%$ heat inactivated fetal bovine serum (FBS) and $1 \%$ penicillin streptomycin, at $37^{\circ} \mathrm{C}$ in a humidified atmosphere containing $5 \% \mathrm{CO}_{2}$. The MTT assay was used to evaluate the antiproliferative activities of the protein against the cancer cell lines. The assay depends on the cleavage of tetrazolium salt into formazan blue by the mitochondrial enzyme succinate dehydrogenase. The conversion takes place only in living cells and the amount of formazan produced is proportional to the number of viable cells present. Thus, the MTT assay is potentially useful for assaying both cell viability and the antiproliferative activities of materials.

\section{RESULTS AND DISCUSSION}

This section presents the result of the cytotoxicity of jackfruit seed crude extract jacalin extracted from crude protein of jackfruit seed powder on the growth of MCF7 cell lines, as evaluated by MTT assay [20]. The MTT assay is a common practice for studying the action of natural products on cell viability, proliferation and cytotoxicity. This assay is based on reduction of tetrazolium salt to a purple insoluble formazan by metabolically active cells [1]. The absorbance of the solubilized formazan is taken as a measure of the number of living cells.

The cytotoxic effects of lectin from jackfruit seed (crude protein and jacalin extract) on the viability of human breast cancer cell (MCF7) was evaluated by MTT assay. Figure 1 shows the cytotoxic effects examined at
50, 100 and $200 \mu \mathrm{g} / \mathrm{mL}$ concentration of sample and compared with jacalin standard. Meanwhile, in Figure 2, a graph of percentage of cell viability was plotted to determine the concentration of $50 \%$ inhibition of cell viability, also known as $\mathrm{IC}_{50}$. The inhibitory concentration required to reduce $50 \%$ of cell viability $\left(\mathrm{IC}_{50}\right)$ was then compared to the untreated control. The results were calculated based on treated MCF7 cells with a density of $1 \times 10^{5}$ cells $/ \mathrm{mL}$, treated for $72 \mathrm{hr}$ in a 96-well plate with crude protein as well as jacalin extract, and compared with jacalin standard.

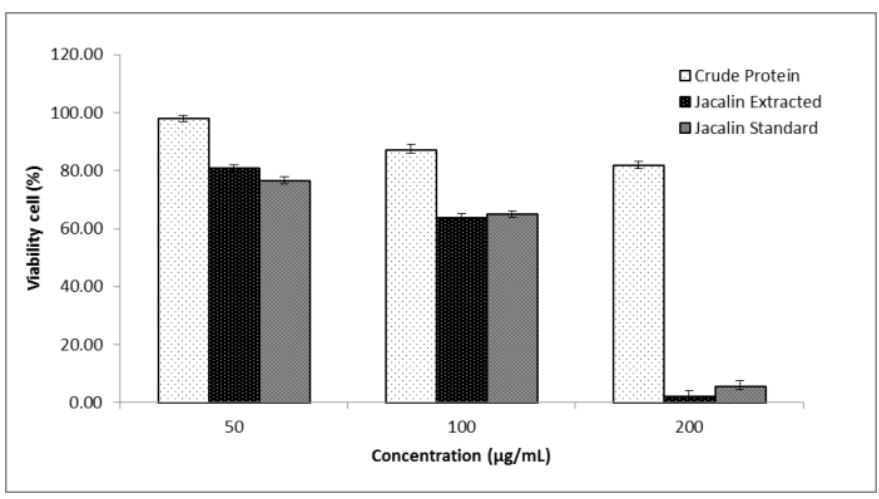

Figure 1: The effects of crude protein, jacalin extract and jacalin standard on viability of MCF7 cell lines were examined at 50, 100 and $200 \mu \mathrm{g} / \mathrm{mL}$ concentration.

Figure 1 shows that the crude protein did not have much effect on the viability of MCF7 cell, as 50, 100 and $200 \mu \mathrm{g} / \mathrm{mL}$ concentrations of sample gave the result of $91.70,89.00$ and $86.00 \%$ cell viability, respectively. Overall, there was only a minor decrease in cell viability (dropping only $16.70 \%$ ) with crude protein, and it may be assumed that it would not achieve $\mathrm{IC}_{50}$ for inhibition of this cancer cell inhibition. Whereas jacalin extract showed a large drop from 200 to $50 \mu \mathrm{g} / \mathrm{mL}$, which is a $92.10 \%$ drop in cancer cell viability. The results of the jacalin extract show an almost similar trend to jacalin standard, whereby jacalin standard also had a large decrease in cell viability $(93.00 \%)$. From this result it can be concluded that the jacalin extract was better than crude protein in inhibiting the viability of MCF7 cancer cell.

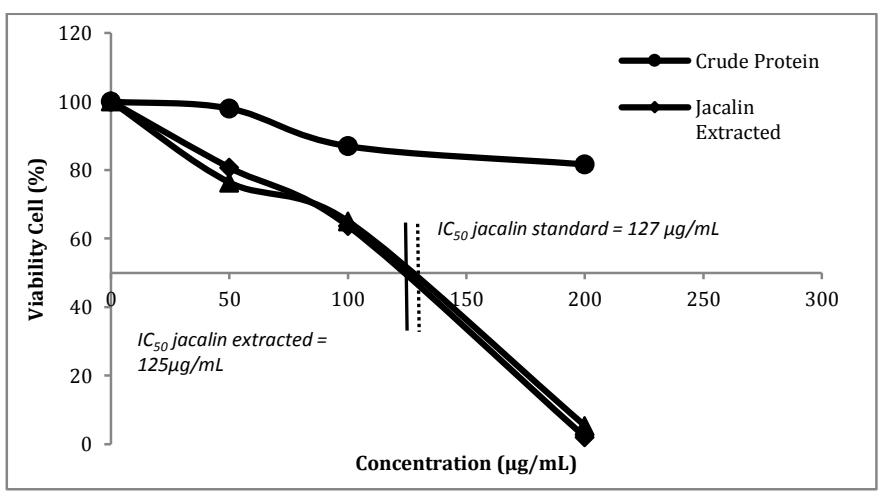

Figure 2: A graph plotting the percentage of cell viability versus concentration of jacalin extract and the concentration that gave $50 \%$ inhibition of cell viability $\left(\mathrm{IC}_{50}\right)$ was determined.

As shown in Figure 2, cytotoxic effects towards MCF7 cell reached IC ${ }_{50}$ for jacalin extract and jacalin standard at concentrations 125 and $127 \mu \mathrm{g} / \mathrm{mL}$, respectively. This is dissimilar to crude protein, which still did not reach $\mathrm{IC}_{50}$ even when extended till $200 \mu \mathrm{g} / \mathrm{mL}$ concentration. This means extraction of crude protein using reversed micelles was selective in filtering compounds, contributing to the cytotoxic effect towards MCF7 cell. On the other hand, the jacalin extract result was parallel with jacalin standard, so it can be concluded that the jacalin extract has the same biological function as jacalin standard.

The overall results in Figure 1 and 2 shows that jacalin extract had better inhibition effect on MCF7 cancer cells compared to crude protein. Jacalin was extracted by reversed micelles liquid-liquid extraction, which was selective for lectin which had the effect of inhibiting MCF7 cells. Besides that, from this result it can be concluded that the extract contained jacalin since its biological effect on MCF 7 cancer cell was similar to jacalin standard. This is related to a previous study, who mentioned that jacalin 
has been used to study tissue binding properties in breast and thyroid cancer cell [12].

\section{CONCLUSION}

The results of the present study have demonstrated that crude protein and jacalin extracted from jackfruit seed inhibit the cell viability for MCF7 cell lines. However, crude protein had a slowed down trend of decreasing cell viability for both types and did not reach $\mathrm{IC}_{50}$. Therefore, it was not worth it to raise its concentration and instead it was recommended to extract jacalin from the crude protein prior to treatment. Through detailed in vitro study studies, the results propose that lectin derivatives from jackfruit seed called jacalin have the potential to inhibit the growth of cancer cells. These findings are parallel to the suggestion by Kabir that jacalin has potential as a therapeutic agent for cancer and it has been used as a histochemical reagent to study tissue binding properties in benign and malignant lesions of the breast and the thyroid.

Upon determining the inhibitory effect of jacalin on MCF7 cell lines, further study identified that jacalin extract was more effective compared to crude protein in treatment towards reducing cell viability. The reason for this is that crude mixtures of lectin are complicated and unknown in their details compared to extracts with selective and filtered compounds. Other than that, lectins are involved in cell recognition and aggregation, but all biological functions of lectins in these organisms have not yet been determined. The mechanism of the cytotoxic activity of jacalin is still unknown, and it could reveal some new and interesting facts about the role of lectins as a treatment agent in prohibiting the viability of cancer cells. Meanwhile, a report by a researcher found that native jacalin from $A$. Intergrifolia seed was a cytotoxic inhibitor of proliferation of epidermoid carcinoma (A431) and human colorectal carcinoma (HT29), and suggested that jacalin induces cytotoxicity by facilitating protein-protein interactions that impair the functions of the cell, thus making the cell more susceptible to death due to stress. It has been proved that jacalin can be a prominent agent in cancer cell treatment today as well as in the future. Furthermore, the haemagglutinating activity of jackfruit seed protein was found to be specifically and most effectively inhibited by $\mathrm{N}$-acetyl galactosamine, and to a lesser degree by galactose, therefore suggesting that the agglutinating factor is probably a lectin specific for $N$-acetyl galactosamine.

\section{ACKNOWLEDGEMENT}

The research work was sponsored under Research initiative grant scheme (RIGS), IIUM

\section{REFERENCES}

[1] Abu Bakar, M.F., Mohamad, M., Rahmat, A., Burr, S., Fry, J.R. 2010. Cytotoxicity, cell cycle arrest, and apoptosis in breast cancer cell lines exposed to an extract of the seed kernel of Mangifera pajang (bambangan). Food and Chemical Toxicology: An International Journal Published for the British Industrial Biological Research Association, 48 (6), 1688-97.

[2] Petrossian, K., Banner, L.R., Oppenheimer, S.B. 2007. Lectin binding and effects in culture on human cancer and non-cancer cell lines: examination of issues of interest in drug design strategies. Acta Histochemica, 109 (6), 491-500.

[3] Saini, R.K., Nile, S.H., and Park, S.W. 2015. Carotenoids from fruits and vegetables: Chemistry, analysis, occurrence, bioavailability and biological activities. Food Research International, 76 (3), 735-750.

[4] Deepa, M., Sureshkumar, T., Satheeshkumar, P.K., Priya, S. 2012. Purified mulberry leaf lectin (MLL) induces apoptosis and cell cycle arrest in human breast cancer and colon cancer cells. Chemico-Biological Interactions, 200 (1), 38-44.

[5] Ghazarian, H., Idoni, B., Oppenheimer, S.B. 2011. A glycobiology review: carbohydrates, lectins and implications in cancer therapeutics. Acta Histochemica, 113 (3), 236-47.
[6] Swami, S.B., Thakor, N.J., Haldankar, P.M., Kalse, S.B. 2012. Jackfruit and Its Many Functional Components as Related to Human Health: A Review. Comprehensive Reviews in Food Science and Food Safety, 11 (6), 565-576.

[7] Kim, J., Jayaprakasha, G.K., Uckoo, R.M., Patil, B.S. 2012. Evaluation of chemo preventive and cytotoxic effect of lemon seed extracts on human breast cancer (MCF-7) cells. Food and Chemical Toxicology: An International Journal Published for the British Industrial Biological Research Association, 50 (2), 423-30.

[8] Mahassni, S.H., Al-Reemi, R.M. 2013. Apoptosis and necrosis of human breast cancer cells by an aqueous extract of garden cress (Lepidium sativum) seeds. Saudi Journal of Biological Sciences, 20 (2), 131-9.

[9] Arslan, M.I., Chulavatnatol, M. 2000. Characterisation of Jack fruit lectin. Bangladesh Medical Research Council Bulletin, 26 (1), 23-6.

[10] DaSilva, L.L.P., de Molfetta-Machado, J.B., Panunto-Castelo, A., Denecke, J., Goldman, G.H., Roque-Barreira, M.C., Goldman, M.H.S. 2005. cDNA cloning and functional expression of $\mathrm{KM}+$, the mannose-binding lectin from Artocarpus integrifolia seeds. Biochimica et Biophysica Acta, $1726(3), 251-60$.

[11] Laija, S.N., Smitha, L.S., Remani, P. 2010. Isolation and Partial Characterization of Two Plant Lectins. Journal of Biological Sciences, 2 (4), 232-237.

[12] Kabir, S. 1998. Jacalin: a jackfruit (Artocarpus heterophyllus) seedderived lectin of versatile applications in immunobiological research. Journal of Immunological Methods, 212 (2), 193-211.

[13] Welty, L.A.Y., Heinrich, E.L., Garcia, K., Banner, L.R., Summers, M.L., Baresi, L., Oppenheimer, S.B. 2006. Analysis of unconventional approaches for the rapid detection of surface lectin binding ligands on human cell lines. Acta Histochemica, 107 (6), 411-20.

[14] Naczk, M., Shahidi, F. 2006. Phenolics in cereals, fruits and vegetables: Occurrence, extraction and analysis. Journal of Pharmaceutical and Biomedical Analysis, 41 (5), 1523-1542.

[15] Sahasrabuddhe, A., Ahmed, N., Krishnasastry, M.V. 2006. Stressinduced phosphorylation of caveolin-1 and p38, and down-regulation of EGFr and ERK by the dietary lectin jacalin in two human carcinoma cell lines. Cell Stress and Chaperones, 11 (2), 135-47.

[16] Berquin, I.M., Edwards, I.J., Chen, Y.Q. 2008. Multi-targeted therapy of cancer by omega-3 fatty acids. Cancer Letters, 269 (2), 363-377.

[17] Silva, M.C.C., de Paula, C., Ferreira, J.G., Paredes-Gamero, E.J., Vaz, A.M.S.F., Sampaio, M.U., Oliva, M.L.V. 2014. Bauhinia forficata lectin (BfL) induces cell death and inhibits integrin-mediated adhesion on MCF7 human breast cancer cells. Biochimica et Biophysica Acta, 1840 (7), 226271.

[18] Pajic, I., Kljajic, Z., Dogovic, N., Sladic, D., Juranic, Z., Gasic, M.J. 2002. A novel lectin from the sponge Haliclona cratera: isolation, characterization and biological activity. Comparative Biochemistry and Physiology. Toxicology and Pharmacology: CBP, 132 (2), 213-21.

[19] Queiroz, A.F.S., Silva, R.A., Moura, R.M., Dreyfuss, J.L., ParedesGamero, E.J., Souza, A.C.S., De Sales, M.P. 2009. Growth inhibitory activity of a novel lectin from Cliona varians against K562 human erythroleukemia cells. Cancer Chemotherapy and Pharmacology, 63 (6), 1023-1033.

[20] Whelan, S.A., Lu, M., He, J., Yan, W., Saxton, R.E., Faull, K.F., Chang, H.R. 2009. Mass spectrometry (LC-MS/MS) site-mapping of N-glycosylated membrane proteins for breast cancer biomarkers. Journal of Proteome Research, 8, 4151-4160. 